\title{
How best to survive any respiratory virus infection
}

\begin{abstract}
This work details the interaction of the human body-field with the electromagnetic phenomena of the biosphere of the earth. The overall Human body-field is described in detail and the role of healing modalities in maintaining the harmony of the Human bodyfield is elucidated. A protocol for healer-client interaction to harmonize the client Human body-field is presented.
\end{abstract}

Keywords: RNA, DNA, beta-glucans, zinc, vitamin C, chinese medicine
Volume 13 Issue 3 - 2020

\author{
Edward F Block \\ Block Institute for Astrobiological Studies, USA
}

Correspondence: Edward F Block, Block Institute for Astrobiological Studies, 160 Holiday Loop, Unit 2 New Braunfels, TX 78132, USA,

Email edward.f.block.iv@gmail.com

\section{Opinion}

The stratgies offered here are taken from both Eastern and Western medical traditions. It may not be possible to prevent infection if you are among a lot of other people in everyday situations. Like any illness, you may be able to pass on the infection without yet showing any symptoms. It is best to avoid any areas where someone has been actively coughing for at least $1 / 2$ hour. Contrary to popular opinion, most face masks will not prevent inhalation of virus particles because the particles readily pass through the spaces of the material that form the supposed barrier. Virus particles are very tiny and the in breath produces very powerful local air flow characteristics. Wash your hands with soap and water often and avoid touching your face, which is not as easy as it sounds. Supposed hand sanitizers just smear the surface contaminants around and have not been shown to actually kill anything. Do you not just love marketing ploys??

The virus is a clump of RNA/DNA surrounded by proteins. The proteins allow the virus to make contact with an infectable surface and inject the RNA/DNA material into a cell to infect it. The RNA/DNA then takes over the normal cellular metabolism to make more virus particles instead of normal cellular materials. Thus, one of the most effective forms of disease prevention is to disinfect surfaces where virus particles may have been deposited with substances that denature the proteins surrounding the RNA/DNA. This will prevent attachment and injection of the RNA/DNA into the cell.

According to Traditional Chinese Medicine, the time that you are most suseptible to infection is about 3 to $5 \mathrm{PM}$ as this is opposite to the body clock of the Lungs, 3 to 5 AM. Thus it is best to avoid crowds and gatherings of people at this time. Actively take prcautions if you must be out and about at this time if day. Household bleach at about $3 \%$ concentration is perhaps the best and most easily obtainable disinfectant substance. Wipe areas to be disinfected and allow to air dry. You may wash various cloth articles in the washer with bleach added, read the instruction label on the bottle. Do not immerse iron containing metal items in a bleach solution as it will cause the metal to corrode. To disinfect areas upon your body, use a 7\% hydrogen peroxide solution and let air dry if possible. Twenty percent hydrogen peroxide solutions may be obtained from a beauty supply store. You may immerse all manner of items for disinfection in diluted (3\% to $7 \%$ ) hydrogen peroxide.

Consult the Federal Drug Administration and Centers for Disease Control for guidelines of commercially available substances that will do the job of disinfection and under what conditions of use. The best strategy to survive any infection is to maintain optimum health - get enough rest, exercise regularly, eat healthful meals and boost your immune system. In order to boost your immune system (apart from getting enough rest, getting enough exercise and eating healthily) you will need the following items - beta-glucans, zinc, vitamin $\mathrm{C}$ and Elderberry Extract.

Beta-glucans are in the cell walls of fungi, algae, bacteria, yeasts and cereals. Healthfood supplements are expensive but mushrooms and whole cereals are not. Refined cereals and flours are not worth bothering with for getting the beta-glucans that you need. You need the whole cereals in some form to make healthy eatables. There are many mushrooms that originated in East Asia that are touted for their healthy effects - Shiitake, Maitake are examples. But also in the West there are Truffles and Morels, Button and Oyster mushrooms. A diet including these cooked mushrooms, and they need to be cooked to break down the cell walls, will suffice. Zinc is found in most foods and may be supplied as a supplement as zinc gluconate, maleate or fumerate (50 $\mathrm{mg}$ three times a day).

Vitamin C or Ascorbic Acid (Ascorbate in a complexed form) is found in many fruits but especially the Citrus family. Lemons and limes are best for making drinks and cooking. This is handy since you will need to drink almost to excess while infected and that will be a lot of Lemonade, slightly sweetened. The Elderberry plant extracts have been known for many years to have beneficial effects upon all manner of internal infections and to boost the immune system. There are numerous online sources of products and you may find them in the larger food markets. Follow the instructions found upon the bottle. You will most likely be feverous during your infection. There are many food items that will assist you in taking control of your fever. The fever is a natural result of your body to the stress of an infection. It is when your fever gets to be beyond 102 degrees Fahrenheit that you will need to take action. Iceberg lettuce is a known cooler. The flower known as Roselle (Hybiscus sabdariffa) is also a known cooler. The spice Cimmamon is added to many food dishes to curb the effects of the Traditional Chinese Medicine (TCM) condition known as Dampness Heat. It is included in all TCM anti-fever herbal formulas. The Cranberry fruit is also a cooler and this is why it is included as an essential component of the Thanksgiveng meal, to cool the Dampness Heat that eating lots of turkey predisposes one to having. So include these items in your food - salads for lettuce, drinks with lemons for Roselle and desserts for Cinnamon (Pumpkin pie).

So get lots of rest, drink lots of fluids. boost your immune system and you will get through the infection just fine! 


\section{Acknowledgments}

None.

\section{Conflicts of interest}

\footnotetext{
The authors declare that there are no conflicts of interest.
}

\section{Funding}

None. 